\title{
Incidence and Mortality of Bladder Cancer and their Relationship with Development in Asia
}

\author{
Reza Pakzad ${ }^{1,2}$,Abdollah Mohammadian-Hafshejani ${ }^{1,3}$, Mahdi Mohammadian $^{4}$, \\ Iraj Pakzad ${ }^{5,6}$, Saeid Safiri ${ }^{7}$, Salman Khazaei ${ }^{8}$, Hamid Salehiniya ${ }^{1,9 *}$
}

\begin{abstract}
Background: Over the past decade, bladder cancer was associated with a significant increase. Given the importance of the impact of socioeconomic status on the distribution of cancer incidence and mortality, and the need to information on these parameters for prevention planning, the aim of this study was to evaluate data for bladder cancer and their relationship with human development index (HDI) and its components in Asia in 2012. Materials and Methods: The study was conducted based on data from the world data of cancer and the World Bank (including the HDI and its components). The incidence and mortality rates were drawn for Asian countries. To analyze data, correlation tests between incidence and death rates, and HDI and its components were employed with a significance level of 0.05 using SPSS software. Results: A total incidence of 696,231 cases $(68.7 \%$ in males and 31.3\% in females, sex ratio of 2.19:1) and 524,465 deaths $(67.0 \%$ in men and $32.9 \%$ in women, sex ratio was 2.03:1) were recorded in Asian countries in 2012. Correlation between HDI and standardized incidence rate was 0.241 overall $(p=0.106), 0.236$ in $\mathrm{men}(\mathrm{p}=\mathbf{0 . 1 1 4})$ and $-\mathbf{0 . 2 5 0}$ in women $(\mathrm{p}=0.094)$. Also between HDI and standardized mortality rate $0.025(p=0.871)$ in men $0.118(p=0.903)$ and in women $0.014(p=0.927)$. Conclusions: Bladder cancer incidence is higher in developed countries, but the rate is declining, and in less developed and developing countries it is growing. There was no statistically significant correlation between the standardized incidence rate of bladder cancer and the HDI and its dimensions in Asia, except for the level of education.
\end{abstract}

Keywords: Bladder cancer - incidence - mortality - HDI - Asia - development

Asian Pac J Cancer Prev, 16 (16), 7365-7374

\section{Introduction}

Cancer is a major burden of disease and public health concern in world (Keyghobadi et al., 2014; Razi et al., 2014). Among cancers, bladder cancer is the seventh most common cancer in men, while seventeenth most common cancer in women worldwide. It is considered the most common urinary tract and genital cancer (Akbari et al., 2008; Burger et al., 2013; Ferlay et al., 2015). Over the past decade, bladder cancer was associated with a significant increase, so that in 2002, over 357,000 cases of bladder cancer were reported in the world (Murta-Nascimento et al., 2007). However, from almost 430,000 cases in 2012 in the world, 165,000 people had died (Ferlay et al., 2013; Lyon, 2013; Malats and Real, 2015). The incidence of bladder cancer in men is three to four times higher than in women. Seven percent of all new cancer cases were men, but only women include $2 \%$ of new cases of the cancer
(Ahmadi et al., 2012).

Distribution of cancer in the world is different. Two thirds of new cases of bladder cancer occur in developing countries (Ploeg et al., 2009; Yavari et al., 2009). The difference in the incidence of bladder cancer in the world may be not only for the causal factors, but also due to the cancer registry systems (Malats and Real, 2015). However, it is predicted cancer incidence in developing countries will increase in the future, and a greater burden is devoted to the disease (Ploeg et al., 2009). There are several causal factors for bladder cancer, but two main causes of the cancer are smoking and occupational exposure to chemicals in the environment (Kogevinas et al., 2003; Ploeg et al., 2009; Yavari et al., 2009). In terms of morphology, in developed countries, about $90 \%$ of all bladder cancer cases are transitional cell carcinoma, resulting from $\mathrm{f}$ the smoke and chemicals, $5 \%$ squamous cell carcinomas, and $2 \%$ adenocarcinomas. However,

${ }^{1}$ Department of Epidemiology and Biostatistics, School of Public Health, Tehran University of Medical Sciences, ${ }^{9}$ Minimally Invasive Surgery Research Center, Iran University of Medical Sciences, Tehran, ${ }^{2}$ Department of Epidemiology, Faculty of Health, ${ }^{5}$ Department of Microbiology, Medical School, ${ }^{6}$ Clinical Microbiology Research center, Ilam University of Medical Sciences, Ilam, ${ }^{3}$ Department of Social Medicine, School of Medicine, Rafsanjan University of Medical Sciences, Rafsanjan, ${ }^{4}$ Isfahan University of Medical Sciences, Isfahan, ${ }^{7}$ Department of Public Health, School of Nursing and Midwifery, Maragheh University of Medical Sciences, Maragheh, ${ }^{8}$ Department of Epidemiology and Biostatistics, School of Public Health, Hamadan University of Medical Sciences, Hamadan, Iran *For correspondence: alesaleh70@yahoo.com 
in developing countries, $75 \%$ cases are squamous cell carcinomas, due to exposure to parasites, such as Schistosoma haematobium (Kirkali et al., 2005; Creel, 2007), which is responsible for the incidence of most cases in Egypt, where the highest incidence of bladder cancer in the world $(37.1$ per 100,000$)$ was observed (Ploeg et al., 2009). It is estimated that the mortality rate for bladder cancer is 10 per 100,000 for men and 2.4 thousand per 100,000 for women. Although the mortality rate for the cancer depends on the stage of cancer and development levels of a region. It is shown that the mortality rate for bladder cancer in developed countries has a decreasing trend in the last half century (Yavari et al., 2009). Incidence and prevalence of bladder cancer increases with age, so that the peak its incidence is the seventh and eighth decades of life (Malats and Real, 2015). Although screening is not recommended for bladder cancer, studies have shown that the use of Hematuria home screening can reduce deaths from bladder cancer (Messing et al., 1995; Botteman et al., 2003). Studies have shown that the incidence and survival of bladder cancer is so strongly influenced by socioeconomic status. In other words, bladder cancer survival remarkably decreases in low socioeconomic status (Adler and Ostrove, 1999). It is also shown that people with high knowledge level expose lower to bladder cancer risk factors, including smoking. As a result they less suffer from bladder cancer (Yang et al., 2010). Also, in those with high education and income, better bladder cancer survival is observed (Mackillop et al., 1997; Hussain et al., 2008).

To investigate the status of countries, indicators are defined. One of the indicators is Human Development Index (HDI). The index assesses the position of a country in three basic aspects of development, and is a composite index of longevity, knowledge, and standard of living. Longevity is measured with life expectancy at birth, knowledge with potential years of education, and adequate standard of living with income or per GDP capita (Malik, 2013).

A number of studies showed the effective role of HDI in cancer incidence and mortality (Ghoncheh et al., 2015). There was no a comprehensive study on bladder cancer incidence and mortality in Asia. It is necessary to know information on incidence and mortality for health planning and research activities. Considering the possible role, the aim of this study was to evaluate the incidence and mortality of the cancer, and their relationship with HDI and its components in Asia in 2012.

\section{Materials and Methods}

This study was an ecologic study in Asia for assessment the correlation between age-specific incidence and mortality rate (ASR) with Human Development Index (HDI) and its details that include: Life expectancy at birth, Mean years of schooling and Gross national income per capita. Data about the age-specific incidence and mortality rate (ASR) for every Asian counter for year 2012 get from global cancer project that available in (http://globocan. iarc.fr/Default.aspx) and Human Development Index (HDI) from Human Development Report 2013 (Malik,
2013) that include information about HDI and its details for every country in the word for year 2012.

Method of estimate the age-specific Incidence and mortality rates in global cancer project by international agency for research on cancer

\section{Age-specific incidence rate estimate}

The methods of estimation are country specific and the quality of the estimation depends upon the quality and on the amount of the information available for each country. In theory, there are as many methods as countries, and because of the variety and the complexity of these methods, an overall quality score for the incidence and mortality estimates combined is almost impossible to establish. However an alphanumeric scoring system which independently describes the availability of incidence and mortality data has been established at the country level. The combined score is presented together with the estimates for each country with an aim of providing a broad indication of the robustness of the estimation.

The methods to estimate the sex- and age-specific incidence rates of cancer for a specific country fall into one of the following broad categories, in priority order:

1- Rates projected to 2012 (38 countries)-2- Most recent rates applied to 2012 population (20 countries)3-Estimated from national mortality by modelling, using incidence mortality ratios derived from recorded data in country-specific cancer registries (13 countries)-4Estimated from national mortality estimates by modelling, using incidence mortality ratios derived from recorded data in local cancer registries in neighboring countries (9 European countries)-5-Estimated from national mortality estimates using modelled survival (32 countries)-6Estimated as the weighted average of the local rates (16 countries)-7- One cancer registry covering part of a country is used as representative of the country profile (11 countries)-8-Age/sex specific rates for "all cancers" were partitioned using data on relative frequency of different cancers (by age and sex) (12 countries)-9- The rates are those of neighboring countries or registries in the same area (33 countries) (Ferlay et al., 2013; Lyon, 2013; Ferlay et al., 2015).

\section{Age-specific mortality rate estimate}

Depending of the degree of detail and accuracy of the national mortality data, six methods have been utilized in the following order of priority:

1-Rates projected to 2012 (69 countries)-2- Most recent rates applied to 2012 population (26 countries)-3Estimated as the weighted average of regional rates (1 country)-4- Estimated from national incidence estimates by modelling, using country-specific survival ( 2 countries)-5-Estimated from national incidence estimates using modelled survival (83 countries)-6-The rates are those of neighboring countries or registries in the same area (3 countries) (Ferlay et al., 2013; Lyon, 2013; Ferlay et al., 2015).

\section{Human Development Index (HDI)}

Human Development Index (HDI), a composite measure of indicators along three dimensions: life 
expectancy, educational attainment and command over the resources needed for a decent living. All groups and regions have seen notable improvement in all HDI components, with faster progress in low and medium HDI countries. On this basis, the world is becoming less unequal. Nevertheless, national averages hide large variations in human experience. Wide disparities remain within countries of both the North and the South, and income inequality within and between many countries has been rising (Malik, 2013).

\section{Statistical analysis}

In this study, we use of correlation bivariate method for assessment the correlation between age-specific incidence and mortality rate (ASR) with Human Development Index (HDI) and its details that include: Life expectancy at birth, Mean years of schooling and Gross national income (Burger et al.) per capita. Statistical significance was assumed if $\mathrm{P}<0.05$. All reported $\mathrm{P}$-values are two-sided. Statistical analyses were performed using SPSS (Version 15.0, SPSS Inc).

\section{Results}

A total of 696231 , bladder cancer cases were recorded in Asian countries in 2012. Overall, 478,069 cases $(68.66 \%)$ were males, and 218,162 cases $(31.34 \%)$ females. Sex ratio in Asia was 2.19. The five countries with the highest number of new patients were china $(404,996$ cases), Japan (107,898 cases), India (63,097 cases), Korea (31,269 cases), and Vietnam (14,203 cases), respectively. The countries included a total of 621,463 cases $(8.26 \%)$ in Asia.

Among Asian countries, five countries with the highest standardized incidence rates of the cancer were Korea with 41.8 per 100,000 , Mongolia with 32.5 per 100,000 , Japan with 29.9 per 100,000 , China with 22.7 per 100,000 , and Tajikistan with 21.7 per 100,000 , respectively. Five countries with the lowest standardized incidence rates of the cancer were Timor-Leste with 2.3 per 100,000 , Kuwait with 2.6 per 100,000 , Indonesia with 2.8 per 100,000 , Pakistan with 3 per 100,000 , and Thailand with 3.1 per 100,000 , respectively. The number, crude, and standardized incidence rates of the cancer in Asian countries based on sex are presented in Table 1. Countries in the table are sorted from high to low based on the standardized incidence rate. The countries with the highest and lowest standardized incidence rate in both sexes are observable in Table 1 and Figure 1.

However, in2012, in Asia, the number of deaths due to bladder cancer was 524,465 cases, 351,466 cases $(67.01 \%)$ in men and 172,999 cases $(32.92 \%)$ in women. The sex ratio (male to female) of mortality was equal to2.03. The five countries with the highest number of deaths were china (325,166 cases), India (59,041 cases), Japan (52,326 cases), Vietnam (12,931 cases), and Korea (10,746 cases), respectively. The countries included a total of 460,210 cases $(87.74 \%)$ of the total mortality in Asia.

In Asian countries, 5 countries with the highest standardized mortality rates from the cancer were Mongolia with 25.3 per 100,000 , Tajikistan with 19.8 per
100,000 , Kyrgyzstan with 19.6 per 100,000 , Kazakhstan with 18 per 100,000 , and China with 17.9 per 100,000 , respectively. Five countries with the lowest standardized mortality rates from the cancer were Kuwait with 1.6 per 100,000 , Lao PDR with 2.2 per 100,000, Timor-Leste with 2.3 per 100,000 , Thailand with 2.5 per 100,000 , and Indonesia with 2.5 per 100,000 , respectively. The number, crude, and standardized mortality rates of the cancer in Asian countries based on sex are presented in Table 2. Countries in the table are sorted from high to low based on the standardized mortality rate. The countries with the highest and lowest standardized mortality rate are observable in both sexes in Table 2 and Figure 1.

In Table 3, amounts related to HDI and its components for each of the Asian countries (sorted based on HDI) is shown. Accordingly, Asian countries are classified according to HDI as follows: three countries in the very high category, four countries in high, thirty five countries

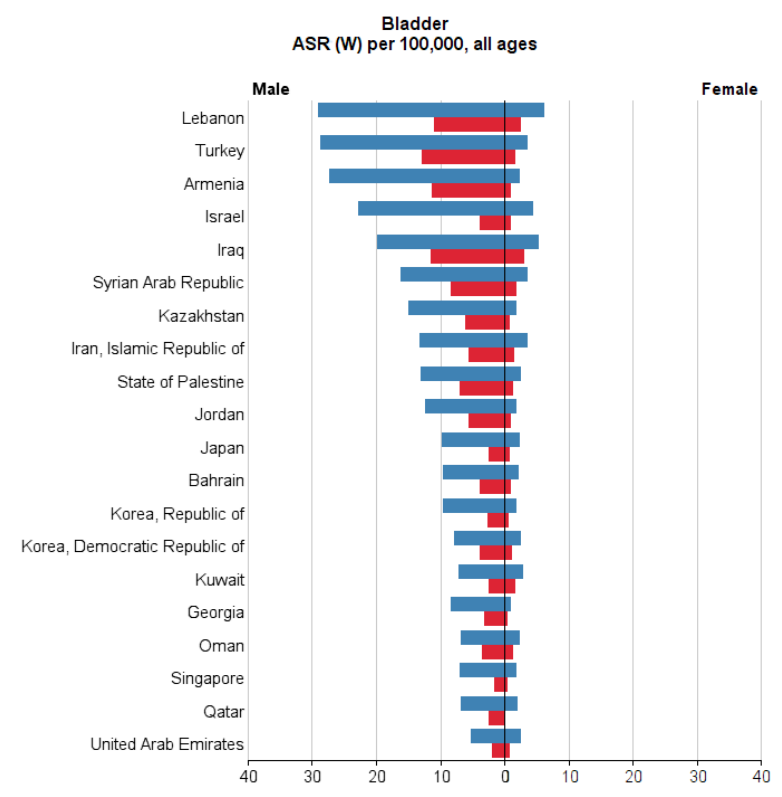

Incidence
Mortality

Figure 1. Standardized and Incidence Rates of Mortality of Bladder Cancer in twenty Asian Countries with the Highest Standardized and Incidence Rates in 2012

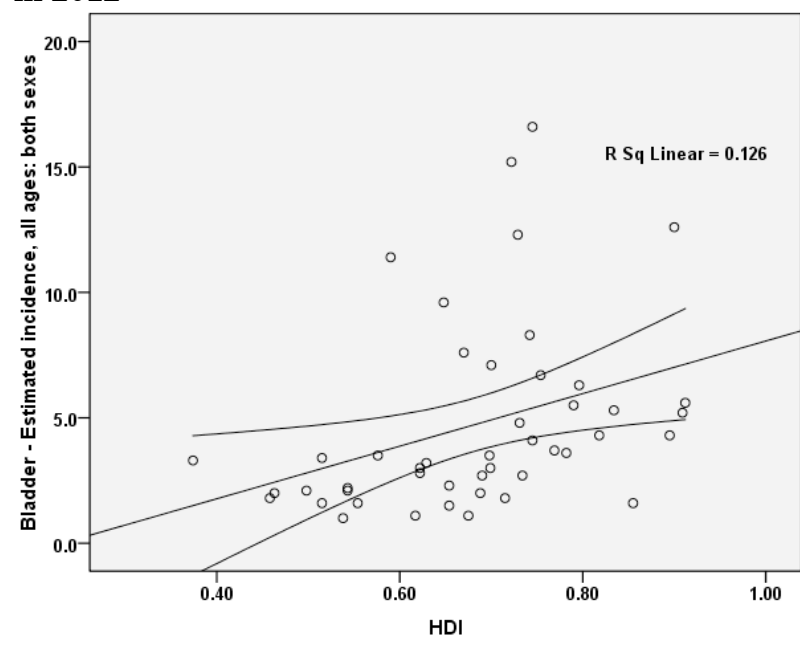

Figure 2. Correlation between HDI and Standardized Incidence of Bladder Cancer in Asia in $\mathbf{2 0 1 2}$ 
Reza Pakzad et al

Table 1. Number, crude and standardized incidence rate of bladder cancer in Asian countries in 2012 (Sorted by age standardized rates from highest to lowest)

\begin{tabular}{|c|c|c|c|c|c|c|c|c|c|c|c|}
\hline \multicolumn{4}{|c|}{$\begin{array}{l}\text { Bladder- Estimated incidence, all ages: } \\
\text { both sexes }\end{array}$} & \multicolumn{4}{|c|}{$\begin{array}{l}\text { Bladder- Estimated incidence, all } \\
\text { ages: male }\end{array}$} & \multicolumn{4}{|c|}{$\begin{array}{l}\text { Bladder- Estimated incidence, all ages: } \\
\text { female }\end{array}$} \\
\hline 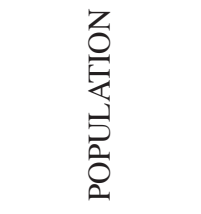 & 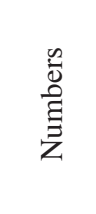 & 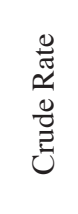 & $\begin{array}{l}\sum \\
\frac{1}{4} \\
\frac{2}{4}\end{array}$ & 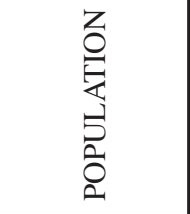 & 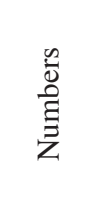 & 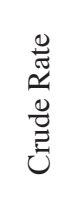 & $\begin{array}{l}\sum \\
\frac{1}{4} \\
\frac{2}{4}\end{array}$ & 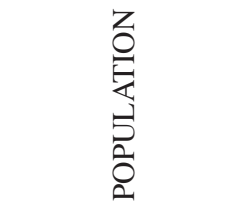 & 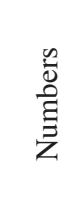 & 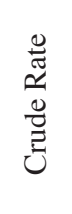 & 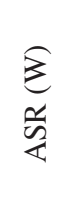 \\
\hline Lebanon & 777 & 18.1 & 16.6 & Lebanon & 618 & 29.5 & 29.1 & Lebanon & 159 & 7.2 & 6.1 \\
\hline Turkey & 10757 & 14.4 & 15.2 & Turkey & 9396 & 25.3 & 28.7 & Iraq & 495 & 3.0 & 5.2 \\
\hline Israel & 1414 & 18.4 & 12.6 & Armenia & 495 & 34.2 & 27.3 & Israel & 281 & 7.2 & 4.3 \\
\hline Armenia & 554 & 17.8 & 12.3 & Israel & 1133 & 29.8 & 22.7 & Turkey & 1361 & 3.6 & 3.5 \\
\hline Iraq & 1840 & 5.5 & 11.4 & Iraq & 1345 & 7.9 & 19.9 & $\begin{array}{l}\text { Syrian Arab } \\
\text { Republic }\end{array}$ & 248 & 2.4 & 3.5 \\
\hline $\begin{array}{l}\text { Syrian Arab } \\
\text { Republic }\end{array}$ & 1300 & 6.2 & 9.6 & $\begin{array}{l}\text { Syrian Arab } \\
\text { Republic }\end{array}$ & 1052 & 9.8 & 16.1 & $\begin{array}{l}\text { Iran, Islamic } \\
\text { Republic of }\end{array}$ & 1066 & 2.9 & 3.4 \\
\hline $\begin{array}{l}\text { Iran, Islamic } \\
\text { Republic of }\end{array}$ & 5343 & 7.1 & 8.3 & Kazakhstan & 945 & 12.0 & 14.9 & Kuwait & 14 & 1.2 & 2.7 \\
\hline $\begin{array}{c}\text { State of } \\
\text { Palestine }\end{array}$ & 153 & 3.6 & 7.6 & $\begin{array}{l}\text { Iran, Islamic } \\
\text { Republic of }\end{array}$ & 4277 & 11.2 & 13.2 & State of Palestine & 27 & 1.3 & 2.5 \\
\hline Jordan & 269 & 4.2 & 7.1 & $\begin{array}{l}\text { State of } \\
\text { Palestine }\end{array}$ & 126 & 5.8 & 13.1 & $\begin{array}{c}\text { Korea, } \\
\text { Democratic } \\
\text { Republic of }\end{array}$ & 495 & 4.0 & 2.5 \\
\hline Kazakhstan & 1146 & 7.0 & 6.7 & Jordan & 235 & 7.1 & 12.3 & $\begin{array}{l}\text { United Arab } \\
\text { Emirates }\end{array}$ & 13 & 0.5 & 2.4 \\
\hline Bahrain & 41 & 3.0 & 6.3 & Japan & 16755 & 27.2 & 9.8 & Oman & 15 & 1.3 & 2.3 \\
\hline Japan & 22042 & 17.4 & 5.6 & Bahrain & 35 & 4.1 & 9.6 & Japan & 5287 & 8.1 & 2.2 \\
\hline Kuwait & 75 & 2.6 & 5.5 & $\begin{array}{c}\text { Korea, } \\
\text { Republic of }\end{array}$ & 3305 & 13.6 & 9.6 & Armenia & 59 & 3.6 & 2.2 \\
\hline Qatar & 32 & 1.7 & 5.3 & Georgia & 279 & 13.8 & 8.4 & Bahrain & 6 & 1.2 & 2.1 \\
\hline $\begin{array}{l}\text { Korea, Repub- } \\
\quad \text { lic of }\end{array}$ & 4097 & 8.4 & 5.2 & $\begin{array}{c}\text { Korea, } \\
\text { Democratic } \\
\text { Republic of }\end{array}$ & 975 & 8.1 & 7.9 & Qatar & 2 & 0.4 & 1.9 \\
\hline Oman & 73 & 2.5 & 4.8 & Kuwait & 61 & 3.5 & 7.1 & Kazakhstan & 201 & 2.4 & 1.8 \\
\hline $\begin{array}{c}\text { Korea, } \\
\text { Democratic } \\
\text { Republic of }\end{array}$ & 1470 & 6.0 & 4.6 & Singapore & 262 & 9.9 & 7.0 & Jordan & 34 & 1.1 & 1.8 \\
\hline $\begin{array}{l}\text { United Arab } \\
\text { Emirates }\end{array}$ & 75 & 0.9 & 4.3 & Qatar & 30 & 2.0 & 6.7 & Singapore & 76 & 2.9 & 1.8 \\
\hline Singapore & 338 & 6.4 & 4.3 & Oman & 58 & 3.4 & 6.7 & $\begin{array}{l}\text { Korea, Republic } \\
\text { of }\end{array}$ & 792 & 3.2 & 1.7 \\
\hline Georgia & 331 & 7.7 & 4.1 & Timor-Leste & 16 & 2.6 & 6.6 & Pakistan & 947 & 1.1 & 1.6 \\
\hline Malaysia & 890 & 3.0 & 3.7 & Malaysia & 718 & 4.8 & 6.1 & Turkmenistan & 33 & 1.3 & 1.5 \\
\hline Saudi Arabia & 596 & 2.1 & 3.6 & $\begin{array}{l}\text { Turkmeni- } \\
\text { stan }\end{array}$ & 96 & 3.8 & 5.9 & Afghanistan & 109 & 0.7 & 1.5 \\
\hline Timor-Leste & 18 & 1.5 & 3.5 & Kyrgyzstan & 97 & 3.6 & 5.8 & China & & 2.1 & 1.4 \\
\hline Turkmenistan & 129 & 2.5 & 3.5 & Indonesia & 5705 & 4.7 & 5.8 & Cambodia & 80 & 1.1 & 1.4 \\
\hline Pakistan & 3967 & 2.2 & 3.4 & Saudi Arabia & 505 & 3.2 & 5.7 & Malaysia & 172 & 1.2 & 1.4 \\
\hline Afghanistan & 458 & 1.4 & 3.3 & $\begin{array}{l}\text { United Arab } \\
\text { Emirates }\end{array}$ & 62 & 1.1 & 5.2 & Tajikistan & 31 & 0.9 & 1.3 \\
\hline Indonesia & 6978 & 2.9 & 3.2 & Tajikistan & 92 & 2.6 & 5.1 & Saudi Arabia & 91 & 0.7 & 1.2 \\
\hline Tajikistan & 123 & 1.7 & 3.0 & Afghanistan & 349 & 2.0 & 5.1 & Myanmar & 267 & 1.1 & 1.2 \\
\hline
\end{tabular}




\begin{tabular}{|c|c|c|c|c|c|c|c|c|c|c|c|}
\hline \multicolumn{4}{|c|}{$\begin{array}{l}\text { Bladder- Estimated incidence, all ages: } \\
\text { both sexes }\end{array}$} & \multicolumn{4}{|c|}{$\begin{array}{l}\text { Bladder- Estimated incidence, all } \\
\text { ages: male }\end{array}$} & \multicolumn{4}{|c|}{$\begin{array}{l}\text { Bladder- Estimated incidence, all ages: } \\
\text { female }\end{array}$} \\
\hline $\begin{array}{l}Z \\
0 \\
\text { 是 } \\
\text { 足 } \\
0 \\
0\end{array}$ & 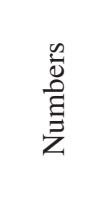 & 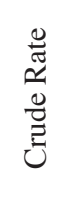 & \begin{tabular}{l}
$\hat{\varepsilon}$ \\
$\hat{z}$ \\
\multirow{2}{*}{}
\end{tabular} & 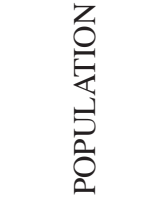 & 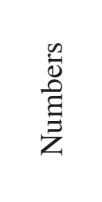 & 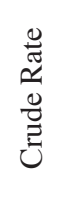 & 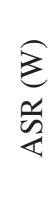 & 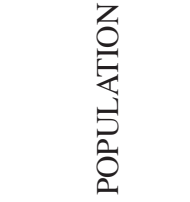 & 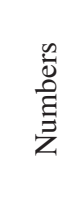 & 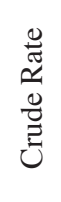 & 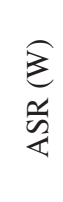 \\
\hline China & 55486 & 4.1 & 3.0 & Pakistan & 3020 & 3.3 & 5.1 & Azerbaijan & 70 & 1.5 & 1.2 \\
\hline Kyrgyzstan & 112 & 2.1 & 2.8 & China & 41993 & 5.9 & 4.8 & Thailand & 616 & 1.7 & 1.2 \\
\hline Azerbaijan & 259 & 2.7 & 2.7 & Azerbaijan & 189 & 4.0 & 4.7 & Indonesia & 1273 & 1.0 & 1.1 \\
\hline Thailand & 2537 & 3.6 & 2.7 & Thailand & 1921 & 5.6 & 4.5 & Uzbekistan & 108 & 0.8 & 0.9 \\
\hline Uzbekistan & 461 & 1.6 & 2.3 & Uzbekistan & 353 & 2.5 & 3.8 & Lao PDR & 20 & 0.6 & 0.9 \\
\hline Cambodia & 203 & 1.4 & 2.2 & Maldives & 5 & 3.1 & 3.8 & Nepal & 101 & 0.6 & 0.9 \\
\hline Myanmar & 870 & 1.8 & 2.1 & Yemen & 166 & 1.3 & 3.6 & Georgia & 52 & 2.3 & 0.9 \\
\hline Lao PDR & 83 & 1.3 & 2.1 & Lao PDR & 63 & 2.0 & 3.5 & Philippines & 310 & 0.6 & 0.9 \\
\hline Maldives & 5 & 1.5 & 2.0 & Nepal & 295 & 1.9 & 3.3 & Bhutan & 2 & 0.6 & 0.9 \\
\hline Nepal & 396 & 1.3 & 2.0 & Brunei & 7 & 3.4 & 3.2 & Sri Lanka & 105 & 1.0 & 0.7 \\
\hline Sri Lanka & 484 & 2.3 & 1.8 & Myanmar & 603 & 2.5 & 3.2 & Timor-Leste & 2 & 0.3 & 0.7 \\
\hline Yemen & 179 & 0.7 & 1.8 & Sri Lanka & 379 & 3.6 & 3.1 & India & 3122 & 0.5 & 0.6 \\
\hline India & 16273 & 1.3 & 1.6 & Cambodia & 123 & 1.7 & 3.1 & Bangladesh & 319 & 0.4 & 0.6 \\
\hline Brunei & 7 & 1.7 & 1.6 & India & 13151 & 2.0 & 2.7 & Kyrgyzstan & 15 & 0.5 & 0.6 \\
\hline Bangladesh & 1672 & 1.1 & 1.6 & Bangladesh & 1353 & 1.8 & 2.5 & Viet Nam & 218 & 0.5 & 0.5 \\
\hline Philippines & 989 & 1.0 & 1.5 & Philippines & 679 & 1.4 & 2.3 & Mongolia & 4 & 0.3 & 0.3 \\
\hline Mongolia & 23 & 0.8 & 1.1 & Mongolia & 19 & 1.4 & 2.2 & Yemen & 13 & 0.1 & 0.3 \\
\hline Viet Nam & 905 & 1.0 & 1.1 & Viet Nam & 687 & 1.5 & 1.8 & Brunei & 0 & 0.0 & 0.0 \\
\hline Bhutan & 5 & 0.7 & 1.0 & Bhutan & 3 & 0.8 & 1.1 & Maldives & 0 & 0.0 & 0.0 \\
\hline
\end{tabular}

in the middle category, three countries in low, and one in the unknown category.

\section{Standardized incidence rate and HDI}

A negative correlation was seen between the standardized incidence rate of bladder cancer and HDI about 0.241 . This association was not statistically significant $(\mathrm{p}=0.106)$. There was a positive correlation between the standardized incidence rate and life expectancy at birth about $0.103(\mathrm{p}=0.498)$, positive correlation between the standardized incidence rate and mean years of schooling about $0.405(\mathrm{p}=0.005)$, and negative correlation between the level of income per each person of the population and the standardized incidence rate equal to $-0.031(\mathrm{p}=0.838)$. (Figure 2)

In men, a positive correlation of 0.236 was observed between the standardized incidence rate of bladder cancer and HDI. It was not statistically significant $(\mathrm{p}=0.114)$. There was a positive correlation between the standardized incidence rate and life expectancy at birth about 0.102 $(\mathrm{p}=0.502)$, a positive correlation between mean years of schooling and the standardized incidence rate about $0.410(\mathrm{p}=0.005)$, and negative correlation between the level of income per each person of the population and the standardized incidence rate equal to -0.044 ( $\mathrm{p}=0.774)$.
In women, a negative correlation of -0.250 was observed between the standardized incidence rate of bladder cancer and HDI. It was not statistically significant $(p=0.094)$. There was a positive correlation between the standardized incidence rate and life expectancy at birth about $0.092(\mathrm{p}=0.545)$, positive correlation between mean years of schooling and the standardized incidence rate about 0.419 ( $\mathrm{p}=0.04)$, and negative correlation between the level of income per each person of the population and the standardized incidence rate equal to -0.015 ( $\mathrm{p}=0.923)$.

\section{The standardized mortality rate and HDI}

There was between the standardized mortality rate for bladder cancer and HDI a negative correlation of 0.025 $(\mathrm{p}=0.871)$, expectancy at birth a negative correlation of $-0.173(\mathrm{p}=0.252)$, mean years of schooling a negative correlation equal to $-0.233(\mathrm{p}=0119)$, and the level of income per each person of population a negative correlation of $-0.213(\mathrm{p}=0.155)$. (Figure 3 )

In men, there was between the standardized mortality rate for bladder cancer and HDI a negative correlation of $0.118(\mathrm{p}=0.903)$, expectancy at birth a negative correlation of $0.165(\mathrm{p}=0.274)$, mean years of schooling a positive correlation equal to $0.253(\mathrm{p}=0.090)$, and the level of income per each person of population a negative 
Reza Pakzad et al

Table 2. Number, Crude and Standardized Mortality Rates for Bladder Cancer in Asian Countries in 2012 (Sorted by age standardized rates from highest to lowest)

\begin{tabular}{|c|c|c|c|c|c|c|c|c|c|c|c|}
\hline \multicolumn{4}{|c|}{$\begin{array}{l}\text { Bladder- Estimated mortality, all } \\
\text { ages: both sexes }\end{array}$} & \multicolumn{4}{|c|}{$\begin{array}{l}\text { Bladder- Estimated mortality, all ages: } \\
\text { male }\end{array}$} & \multicolumn{4}{|c|}{$\begin{array}{l}\text { Bladder- Estimated mortality, all ages: } \\
\text { female }\end{array}$} \\
\hline 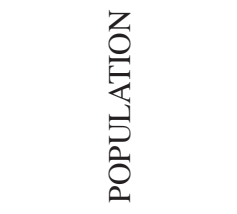 & 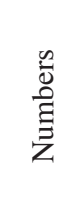 & 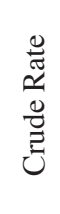 & 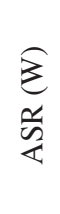 & 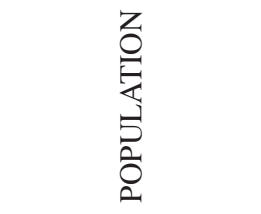 & 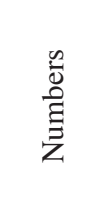 & 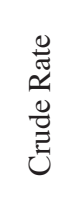 & $\begin{array}{l}\frac{1}{\sqrt{2}} \\
\ll\end{array}$ & 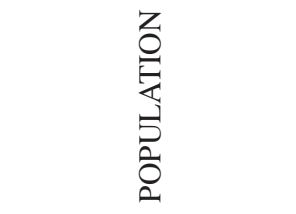 & $\begin{array}{l}\frac{n}{\Delta} \\
\frac{0}{\Xi} \\
z\end{array}$ & $\begin{array}{l}\frac{0}{\tilde{N}} \\
\frac{0}{0} \\
\frac{0}{E}\end{array}$ & $\begin{array}{l}\sum \\
\frac{1}{2} \\
\&\end{array}$ \\
\hline Turkey & 4690 & 6.3 & 6.6 & Turkey & 4099 & 11.0 & 12.8 & Iraq & 275 & 1.6 & 2.9 \\
\hline Iraq & 1016 & 3.0 & 6.3 & Iraq & 741 & 4.4 & 11.4 & Lebanon & 64 & 2.9 & 2.4 \\
\hline Lebanon & 307 & 7.2 & 6.3 & Armenia & 221 & 15.3 & 11.3 & Syrian Arab Republic & 125 & 1.2 & 1.8 \\
\hline Armenia & 248 & 8.0 & 5.0 & Lebanon & 243 & 11.6 & 11.0 & Kuwait & 7 & 0.6 & 1.6 \\
\hline $\begin{array}{l}\text { Syrian Arab } \\
\text { Republic }\end{array}$ & 653 & 3.1 & 4.9 & $\begin{array}{l}\text { Syrian Arab Re- } \\
\text { public }\end{array}$ & 528 & 4.9 & 8.3 & Turkey & 591 & 1.6 & 1.5 \\
\hline State of Palestine & 74 & 1.7 & 3.9 & State of Palestine & 61 & 2.8 & 7.0 & $\begin{array}{l}\text { Iran, Islamic Republic } \\
\text { of }\end{array}$ & 453 & 1.2 & 1.4 \\
\hline $\begin{array}{l}\text { Iran, Islamic } \\
\text { Republic of }\end{array}$ & 2280 & 3.0 & 3.5 & Kazakhstan & 366 & 4.7 & 6.1 & State of Palestine & 13 & 0.6 & 1.2 \\
\hline Jordan & 121 & 1.9 & 3.2 & $\begin{array}{l}\text { Iran, Islamic Re- } \\
\text { public of }\end{array}$ & 1827 & 4.8 & 5.5 & Oman & 7 & 0.6 & 1.2 \\
\hline Kazakhstan & 447 & 2.7 & 2.6 & Jordan & 105 & 3.2 & 5.5 & Afghanistan & 73 & 0.5 & 1.1 \\
\hline Afghanistan & 307 & 0.9 & 2.5 & Timor-Leste & 10 & 1.7 & 4.3 & $\begin{array}{l}\text { Korea, Democratic } \\
\text { Republic of }\end{array}$ & 256 & 2.0 & 1.1 \\
\hline Oman & 34 & 1.2 & 2.5 & Israel & 227 & 6.0 & 3.9 & Pakistan & 571 & 0.6 & 1.0 \\
\hline Bahrain & 11 & 0.8 & 2.4 & Bahrain & 9 & 1.1 & 3.9 & Israel & 77 & 2.0 & 0.9 \\
\hline Israel & 304 & 4.0 & 2.2 & Afghanistan & 234 & 1.4 & 3.8 & Armenia & 27 & 1.6 & 0.9 \\
\hline Timor-Leste & 11 & 0.9 & 2.2 & $\begin{array}{l}\text { Korea, Democratic } \\
\text { Republic of }\end{array}$ & 430 & 3.6 & 3.8 & Jordan & 16 & 0.5 & 0.9 \\
\hline Kuwait & 26 & 0.9 & 2.1 & Oman & 27 & 1.6 & 3.4 & Bhutan & 2 & 0.6 & 0.9 \\
\hline Pakistan & 2396 & 1.3 & 2.1 & Georgia & 112 & 5.5 & 3.1 & Cambodia & 47 & 0.6 & 0.9 \\
\hline $\begin{array}{c}\text { Korea, } \\
\text { Democratic } \\
\text { Republic of }\end{array}$ & 686 & 2.8 & 2.1 & Kyrgyzstan & 50 & 1.9 & 3.1 & Bahrain & 2 & 0.4 & 0.8 \\
\hline Indonesia & 3599 & 1.5 & 1.7 & Pakistan & 1825 & 2.0 & 3.1 & Myanmar & 166 & 0.7 & 0.8 \\
\hline Qatar & 7 & 0.4 & 1.6 & Indonesia & 2940 & 2.4 & 3.1 & Turkmenistan & 15 & 0.6 & 0.7 \\
\hline Turkmenistan & 58 & 1.1 & 1.6 & Turkmenistan & 43 & 1.7 & 2.9 & Tajikistan & 16 & 0.4 & 0.7 \\
\hline Tajikistan & 64 & 0.9 & 1.6 & Tajikistan & 48 & 1.4 & 2.8 & Japan & 2462 & 3.8 & 0.7 \\
\hline $\begin{array}{l}\text { United Arab } \\
\text { Emirates }\end{array}$ & 18 & 0.2 & 1.5 & Korea, Republic of & 955 & 3.9 & 2.6 & United Arab Emirates & 3 & 0.1 & 0.7 \\
\hline Georgia & 133 & 3.1 & 1.5 & Kuwait & 19 & 1.1 & 2.5 & Kazakhstan & 81 & 1.0 & 0.7 \\
\hline Kyrgyzstan & 58 & 1.1 & 1.5 & Japan & 5168 & 8.4 & 2.4 & China & 6762 & 1.0 & 0.6 \\
\hline Japan & 7630 & 6.0 & 1.4 & Qatar & 7 & 0.5 & 2.4 & Korea, Republic of & 375 & 1.5 & 0.6 \\
\hline $\begin{array}{l}\text { Korea, Republic } \\
\text { of }\end{array}$ & 1330 & 2.7 & 1.4 & Yemen & 105 & 0.8 & 2.4 & Nepal & 64 & 0.4 & 0.6 \\
\hline Saudi Arabia & 211 & 0.7 & 1.4 & Saudi Arabia & 178 & 1.1 & 2.3 & Indonesia & 659 & 0.5 & 0.6 \\
\hline China & & 2.0 & 1.4 & China & 20058 & 2.8 & 2.2 & Thailand & 312 & 0.9 & 0.6 \\
\hline Cambodia & 121 & 0.8 & 1.4 & Lao PDR & 39 & 1.2 & 2.2 & Lao PDR & 12 & 0.4 & 0.5 \\
\hline Myanmar & 542 & 1.1 & 1.3 & Thailand & 976 & 2.8 & 2.2 & Uzbekistan & 56 & 0.4 & 0.5 \\
\hline Lao PDR & 51 & 0.8 & 1.3 & Nepal & 189 & 1.2 & 2.2 & Azerbaijan & 31 & 0.7 & 0.5 \\
\hline Thailand & 1288 & 1.8 & 1.3 & Azerbaijan & 83 & 1.8 & 2.1 & Saudi Arabia & 33 & 0.3 & 0.5 \\
\hline Nepal & 253 & 0.8 & 1.3 & Cambodia & 74 & 1.0 & 2.1 & Singapore & 20 & 0.8 & 0.4 \\
\hline
\end{tabular}




\begin{tabular}{|c|c|c|c|c|c|c|c|c|c|c|c|}
\hline \multirow[b]{2}{*}{ 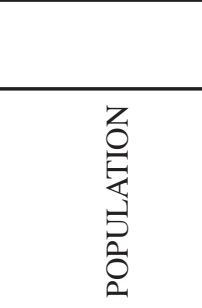 } & \multirow[b]{2}{*}{ 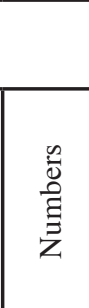 } & \multirow[b]{2}{*}{ 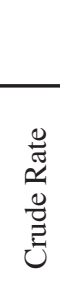 } & \multirow[b]{2}{*}{ 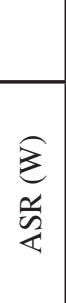 } & \multicolumn{4}{|c|}{$\begin{array}{l}\text { Bladder- Estimated mortality, all ages: } \\
\text { male }\end{array}$} & \multicolumn{4}{|c|}{$\begin{array}{l}\text { Bladder- Estimated mortality, all ages: } \\
\text { female }\end{array}$} \\
\hline & & & & 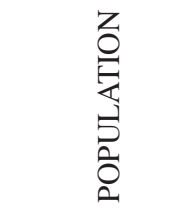 & 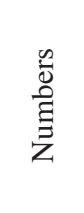 & 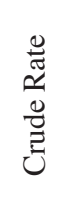 & $\begin{array}{l}\sum \\
\frac{\pi}{4} \\
\&\end{array}$ & 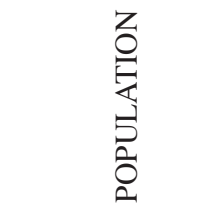 & 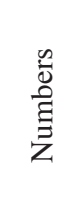 & 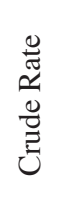 & 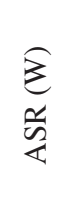 \\
\hline Azerbaijan & 114 & 1.2 & 1.2 & Myanmar & 376 & 1.6 & 2.1 & Philippines & 138 & 0.3 & 0.4 \\
\hline Uzbekistan & 231 & 0.8 & 1.2 & Uzbekistan & 175 & 1.3 & 2.0 & Bangladesh & 196 & 0.3 & 0.4 \\
\hline Yemen & 113 & 0.4 & 1.2 & $\begin{array}{c}\text { United Arab } \\
\text { Emirates }\end{array}$ & 15 & 0.3 & 1.9 & India & 1859 & 0.3 & 0.4 \\
\hline Malaysia & 264 & 0.9 & 1.1 & Malaysia & 221 & 1.5 & 1.9 & Timor-Leste & 1 & 0.2 & 0.4 \\
\hline Bangladesh & 1016 & 0.7 & 0.9 & India & 7664 & 1.2 & 1.6 & Malaysia & 43 & 0.3 & 0.4 \\
\hline Singapore & 75 & 1.4 & 0.9 & Bangladesh & 820 & 1.1 & 1.5 & Georgia & 21 & 0.9 & 0.3 \\
\hline India & 9523 & 0.8 & 0.9 & Singapore & 55 & 2.1 & 1.5 & Sri Lanka & 47 & 0.4 & 0.3 \\
\hline Sri Lanka & 216 & 1.0 & 0.8 & Sri Lanka & 169 & 1.6 & 1.4 & Mongolia & 4 & 0.3 & 0.3 \\
\hline Bhutan & 4 & 0.5 & 0.7 & Philippines & 292 & 0.6 & 1.1 & Kyrgyzstan & 8 & 0.3 & 0.3 \\
\hline Philippines & 430 & 0.4 & 0.7 & Viet Nam & 367 & 0.8 & 1.0 & Viet Nam & 119 & 0.3 & 0.3 \\
\hline Viet Nam & 486 & 0.5 & 0.6 & Brunei & 2 & 1.0 & 0.9 & Yemen & 8 & 0.1 & 0.2 \\
\hline Mongolia & 12 & 0.4 & 0.5 & Mongolia & 8 & 0.6 & 0.8 & Brunei & 0 & 0.0 & 0.0 \\
\hline Brunei & 2 & 0.5 & 0.5 & Bhutan & 2 & 0.5 & 0.7 & Maldives & 0 & 0.0 & 0.0 \\
\hline Maldives & 1 & 0.3 & 0.3 & Maldives & 1 & 0.6 & 0.6 & Qatar & 0 & 0.0 & 0.0 \\
\hline
\end{tabular}

Table 3. Human Development Index and its Components in Asian Countries in 2012

\begin{tabular}{|c|c|c|c|c|c|}
\hline & POPULATION & $\begin{array}{c}\text { Human } \\
\text { Development } \\
\text { Index(HDI) }\end{array}$ & $\begin{array}{l}\text { Life expectancy } \\
\text { at birth }\end{array}$ & $\begin{array}{c}\text { Mean Year of } \\
\text { schooling }\end{array}$ & $\begin{array}{l}\text { Gross national } \\
\text { income (Burger } \\
\text { et al.) per capita }\end{array}$ \\
\hline \multirow{7}{*}{$\begin{array}{c}\text { Very high human } \\
\text { development }\end{array}$} & Japan & 0.912 & 83.6 & 11.6 & 32545 \\
\hline & Korea, Republic of & 0.909 & 80.7 & 11.6 & 28231 \\
\hline & Israel & 0.9 & 81.9 & 11.9 & 26224 \\
\hline & Singapore & 0.895 & 81.2 & 10.1 & 52613 \\
\hline & Brunei & 0.855 & 78.1 & 8.6 & 45690 \\
\hline & Qatar & 0.834 & 78.5 & 7.3 & 87478 \\
\hline & United Arab Emirates & 0.818 & 76.7 & 8.9 & 42716 \\
\hline \multirow{13}{*}{$\begin{array}{l}\text { High human } \\
\text { development }\end{array}$} & Bahrain & 0.796 & 75.2 & 9.4 & 19154 \\
\hline & Kuwait & 0.79 & 74.7 & 6.1 & 52793 \\
\hline & Saudi Arabia & 0.782 & 74.1 & 7.8 & 22616 \\
\hline & Malaysia & 0.769 & 74.5 & 9.5 & 13676 \\
\hline & Kazakhstan & 0.754 & 67.4 & 10.4 & 10451 \\
\hline & Georgia & 0.745 & 73.9 & 12.1 & 5005 \\
\hline & Lebanon & 0.745 & 72.8 & 7.9 & 12364 \\
\hline & Iran, Islamic Republic of & 0.742 & 73.2 & 7.8 & 10695 \\
\hline & Azerbaijan & 0.734 & 70.9 & 11.2 & 8153 \\
\hline & Oman & 0.731 & 73.2 & 5.5 & 24092 \\
\hline & Armenia & 0.729 & 74.4 & 10.8 & 5540 \\
\hline & Turkey & 0.722 & 74.2 & 6.5 & 13710 \\
\hline & Sri Lanka & 0.715 & 75.1 & 9.3 & 5170 \\
\hline
\end{tabular}




\begin{tabular}{|c|c|c|c|c|c|}
\hline & POPULATION & $\begin{array}{c}\text { Human } \\
\text { Development } \\
\text { Index(HDI) }\end{array}$ & $\begin{array}{l}\text { Life expectancy } \\
\text { at birth }\end{array}$ & $\begin{array}{l}\text { Mean Year of } \\
\text { schooling }\end{array}$ & $\begin{array}{l}\text { Gross national } \\
\text { income (Burger } \\
\text { et al.) per capita }\end{array}$ \\
\hline \multirow{20}{*}{$\begin{array}{c}\text { Medium human } \\
\text { development }\end{array}$} & Jordan & 0.7 & 73.5 & 8.6 & 5272 \\
\hline & China & 0.699 & 73.7 & 7.5 & 7945 \\
\hline & Turkmenistan & 0.698 & 65.2 & 9.9 & 7782 \\
\hline & Thailand & 0.69 & 74.3 & 6.6 & 7722 \\
\hline & Maldives & 0.688 & 77.1 & 5.8 & 7478 \\
\hline & Mongolia & 0.675 & 68.8 & 8.3 & 4245 \\
\hline & State of Palestine & 0.67 & 73 & 8 & 3359 \\
\hline & Philippines & 0.654 & 69 & 8.9 & 3752 \\
\hline & Uzbekistan & 0.654 & 68.6 & 10 & 3201 \\
\hline & Syrian Arab Republic & 0.648 & 76 & 5.7 & 4674 \\
\hline & Indonesia & 0.629 & 69.8 & 5.8 & 4154 \\
\hline & Kyrgyzstan & 0.622 & 68 & 9.3 & 2009 \\
\hline & Tajikistan & 0.622 & 67.8 & 9.8 & 2119 \\
\hline & Viet Nam & 0.617 & 75.4 & 5.5 & 2970 \\
\hline & Iraq & 0.59 & 69.6 & 5.6 & 3557 \\
\hline & Timor-Leste & 0.576 & 62.9 & 4.4 & 5446 \\
\hline & India & 0.554 & 65.8 & 4.4 & 3285 \\
\hline & Cambodia & 0.543 & 63.6 & 5.8 & 2095 \\
\hline & Lao PDR & 0.543 & 67.8 & 4.6 & 2435 \\
\hline & Bhutan & 0.538 & 67.6 & 2.3 & 5246 \\
\hline \multirow{6}{*}{$\begin{array}{l}\text { Low human } \\
\text { development }\end{array}$} & Bangladesh & 0.515 & 69.2 & 4.8 & 1785 \\
\hline & Pakistan & 0.515 & 65.7 & 4.9 & 2566 \\
\hline & Myanmar & 0.498 & 65.7 & 3.9 & 1817 \\
\hline & Nepal & 0.463 & 69.1 & 3.2 & 1137 \\
\hline & Yemen & 0.458 & 65.9 & 5.3 & 928 \\
\hline & Afghanistan & 0.374 & 49.1 & 3.1 & 1000 \\
\hline $\begin{array}{l}\text { Other countries or } \\
\text { territories }\end{array}$ & $\begin{array}{c}\text { Korea, Democratic People's } \\
\text { Rep. of }\end{array}$ & - & - & - & - \\
\hline
\end{tabular}

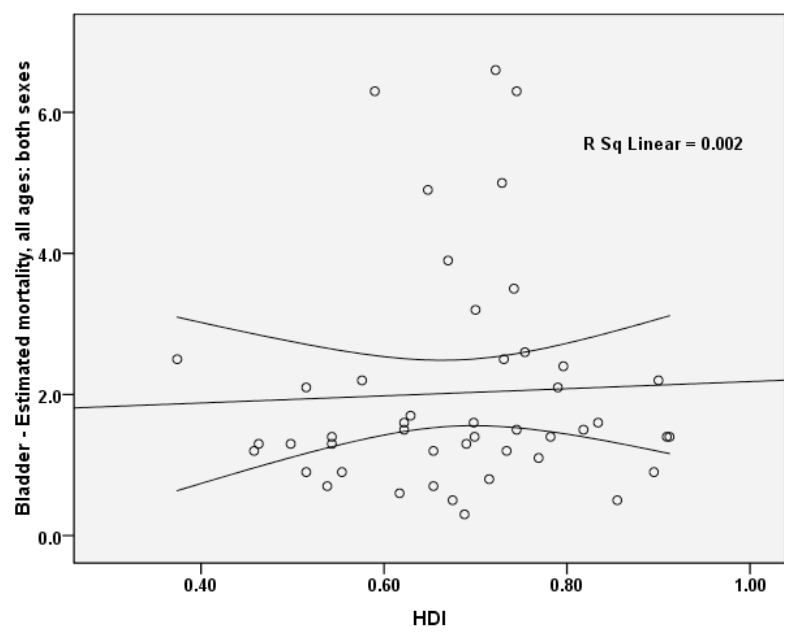

Figure 3. Correlation between HDI and Standardized Mortality Rates for bladder Cancer in Asia in 2012

correlation of $0.223(\mathrm{p}=0.136)$.

In women, there was between the standardized mortality rate for bladder cancer and HDI a negative correlation of $0.014(\mathrm{p}=0.927)$, expectancy at birth a negative correlation of $0.178(\mathrm{p}=0.237)$, mean years of schooling a positive correlation equal to $0.241(\mathrm{p}=0.106)$, and the level of income per each person of population a negative correlation of $0.190(\mathrm{p}=0.207)$.

\section{Discussion}

Less than $35 \%$ of bladder cancer cases occur in Asia. Given that more than 60 percent of people in the world are in Asia, and most countries in the region are developing, it is expected that bladder cancer is associated with a significant increase in the continent. Therefore, health macro policies to deal with this cancer in the future are an important need (Ferlay et al., 2013; Lyon, 2013; Keyghobadi et al., 2014).

Our results showed that most standardized incidence rate of bladder cancer was related to the countries such as Republic of Korea, Mongolia, Japan, China, and Tajikistan. The countries had middle and high HDI. However, in our study, no strong correlation was found between HDI and incidence of bladder cancer. Other studies have shown that 
there was a significant difference the incidence of bladder cancer in higher HDI countries than low HDI countries, but a little difference was observed in the mortality rate between the two groups of countries (Bray et al., 2012). The incidence of bladder cancer rises due to higher exposure to causal factors such as tobacco and chemicals industries, along with development (Burger et al., 2013).

The incidence of bladder cancer in the whole of Asia is three to four times less than European and American countries (Ferlay et al., 2013; Lyon, 2013). It is shown that the incidence and deaths from bladder cancer is declining in Europe and North America, while its incidence is increasing in Asian countries (Ploeg et al., 2009). This is due to shifting in smoking consumption from developed countries to developing countries and less developed, so that in North America and European countries in the early and mid-twentieth century, smoking has declined in both men and women. In the late twentieth century, smoking in less developed countries had significantly increased in men and women (Lopez et al., 1994; Mackay and Eriksen, 2002; Consortium, 2004; Delclos and Lerner, 2008; Razi et al., 2014). The justification for this is that in the last half century, consumption of hazardous industrial chemicals has been decreased in less developed countries, while it has been increased in developing countries in the same period (Delclos and Lerner, 2008; Ploeg et al., 2009).

In our study, no relationship was found between life expectancy as one of the dimensions of the HDI, and the standardized incidence and mortality rates. However, with increasing age, the incidence of bladder cancer increases. The peak of bladder cancer incidence occurs in 65 years, but in many developed countries life expectancy is less than from the peak. As a result, the risk of cancer is lower in them (Malats and Real, 2015). It is also necessary to note that the relationship between age and cancer could be due to previous exposure to risk factors for bladder cancer and their cumulative effect. Therefore, cancer usually occurs in old age.

One of the dimensions of HDI is the level of income, characterized by gross domestic product. In our study, there was no relationship between the income level, and standardized incidence and mortality rates. Studies have shown that cancer mortality is higher in lowincome countries (Soerjomataram et al., 2012). A direct relationship was also observed between income level and bladder cancer survival rate. In other words, the survival rate increases with raising the income level (Mackillop et al., 1997). This may be due to better access to high quality health care. Ezzati revealed that smoking consumption is changing from countries with high income to low-middle income countries. Many lower and middleincome countries still are experiencing the first stage of the epidemiological transition of smoking (Ezzati and Lopez, 2003a; 2003b). Ward showed that even without regard to sex, in low-income countries smoking is twice than high income countries (Ward et al., 2004). Ploeg also indicated that in low-income countries, chemical consumption associated with bladder cancer has been increased, while in the same period, industrial use of such hazardous substances is declining in high-income countries. It is expected in the near future, the incidence of bladder cancer will significantly increase in developing countries (Ploeg et al., 2009).

Another dimension of HDI was the level of education or awareness, characterized by mean years of schooling. In our study, there was no relationship between the education level and standardized death rate. However, a significant relationship was found between standardized incidence rate and the education level. Hussain has shown that the survival rate of bladder cancer is more in people with higher education (Hussain et al., 2008). It seems that in developed countries, better treatment, appropriate lifestyle, reducing smoking, the mechanization of industry and less use of hazardous chemicals, including aromatic amines, better access to health services, and reducing infectious diseases lead to decrease bladder cancer incidence and mortality. In developing and less developed countries, poor lifestyle, smoking, the use of traditional methods in the industry, excessive exposure to dangerous chemicals, and the lack of adequate infrastructure for the implementation of comprehensive cancer control programs lead to more likely bladder cancer incidence and die from it (Messing et al., 1995; Ploeg et al., 2009).

Bladder cancer incidence is higher in developed countries, but the rate is declining, and in less developed and developing countries it is growing. In contrast, bladder cancer mortality in developed countries is less and the survival of bladder cancer is more, while in developing and the less developed countries bladder cancer mortality is higher and survival is lower. There was no statistically significant correlation between the standardized incidence rate of bladder cancer, and the HDI and its dimensions, except for the level of education. No relationship was found between standardized mortality rate, and the HDI and its dimensions.

\section{References}

Adler NE, Ostrove JM (1999). Socioeconomic status and health: what we know and what we don't. Ann New York Academy Sci, 896, 3-15.

Ahmadi M, Ranjbaran H, Amiri MM, et al (2012). Epidemiologic and socioeconomic status of bladder cancer in mazandaran province, northern Iran. Asian Pac J Cancer Prev, 13, 5053-6.

Akbari ME, Hosseini SJ, Rezaee A, et al (2008). Incidence of genitourinary cancers in the islamic republic of Iran: a survey in 2005. Asian Pac J Cancer Prev, 9, 549-52.

Botteman M, Pashos C, Redaelli A, et al (2003). The health economics of bladder cancer. Pharmaco Economics, 21, 1315-30.

Bray F, Jemal A, Grey N, et al (2012). Global cancer transitions according to the human development Index (2008-2030): a population-based study. Lancet Oncol, 13, 790-801.

Burger M, Catto JWF, Dalbagni G, et al (2013). Epidemiology and risk factors of urothelial bladder cancer. European Urol, 63, 234-41.

Consortium A (2004). Tobacco or health in the European Union: past, present and future, European Commission, Directorate General for Health and Consumer Protection.

Creel P (2007). Bladder cancer: epidemiology, diagnosis, and treatment. Semin Oncol Nurs, 23, 3-S10.

Delclos GL, Lerner SP (2008). Occupational risk factors. Scand J Urol Nephrol, 42, 58-63. 


\section{Reza Pakzad et al}

Ezzati M, Lopez AD (2003a). Estimates of global mortality attributable to smoking in 2000. Lancet, 362, 847-52.

Ezzati M, Lopez AD (2003b). Measuring the accumulated hazards of smoking: global and regional estimates for 2000 . Tobacco Control, 12, 79-85.

Ferlay J, Soerjomataram I, Dikshit R, et al (2015). Cancer incidence and mortality worldwide: sources, methods and major patterns in GLOBOCAN 2012. Int J Cancer, 136, 359-86.

Ferlay J, Soerjomataram I, Ervik M, et al (2013). GLOBOCAN 2012 v1. 0, cancer incidence and mortality worldwide: IARC CancerBase No. 11 [internet]. International Agency for Research on Cancer, Lyon. globocan. iarc. fr (accessed 10 October 2014).

Ghoncheh M, Mohammadian-Hafshejani A, Salehiniya H (2015). Incidence and Mortality of Breast Cancer and their Relationship to Development in Asia. Asian Pac J Cancer Prev, 16, 6081-7.

Hussain SK, Lenner P, Sundquist J, et al (2008). Influence of education level on cancer survival in Sweden. Ann Oncol, 19, 156-62.

Keyghobadi N, Rafiemanesh H, Mohammadian-Hafshejani A, et al (2014). Epidemiology and trend of cancers in the province of kerman: southeast of iran. Asian PacJ Cancer Prev, 16, 1409-13.

Kirkali Z, Chan T, Manoharan M, et al (2005). Bladder cancer: Epidemiology, staging and grading, and diagnosis. Urol, 66, 4-34.

Kogevinas M, Mannetje At, Cordier S, et al (2003). Occupation and bladder cancer among men in Western Europe. Cancer Causes Control, 14, 907-14.

Lopez AD, Collishaw NE, Piha T (1994). A descriptive model of the cigarette epidemic in developed countries. Tobacco Control, 3, 242.

Lyon F (2013). International agency for research on cancer; 2013.

Mackay J, Eriksen M (2002). The tobacco atlas (World Health Organization, Geneva).

Mackillop W, Zhang-Salomons J, Groome P, et al (1997). Socioeconomic status and cancer survival in Ontario. JClin Oncol, 15, 1680-9.

Malats N, Real FX (2015). Epidemiology of bladder cancer. Hematol Oncol Clin North Am, 29, 177-89.

Malik K (2013). Human development report 2013. the rise of the south: human progress in a diverse world. the rise of the south: human progress in a diverse world (March 15, 2013). UNDP-HDRO Human Development Reports.

Messing EM, Young TB, Hunt VB, et al (1995). Comparison of bladder cancer outcome in men undergoing hematuria home screening versus those with standard clinical presentations. Urol, 45, 387-97.

Murta-Nascimento C, Schmitz-Drager BJ, Zeegers MP, et al (2007). Epidemiology of urinary bladder cancer: from tumor development to patient's death. World Jo Urol, 25, 285-95.

Ploeg M, Aben KK, Kiemeney LA (2009). The present and future burden of urinary bladder cancer in the world. World J Urol, 27, 289-93.

Razi S, Rafiemanesh H, Ghoncheh M, et al (2014). Changing trends of types of skin cancer in Iran. Asian Pac J Cancer Prev, 16, 4955-8.

Soerjomataram I, Lortet-Tieulent J, Parkin DM, et al (2012). Global burden of cancer in 2008: a systematic analysis of disability-adjusted life-years in 12 world regions. Lancet, 380, 1840-50.

Ward E, Jemal A, Cokkinides V, et al (2004). Cancer disparities by race/ethnicity and socioeconomic status. CA Cancer $J$ Clin, 54, 78-93.

Yang Y, Wang J-J, Wang C-X, et al (2010). Awareness of tobacco- related health hazards among adults in China. Biomed Environ Sci, 23, 437-44.

Yavari P, Sadrolhefazi B, Mohagheghi M, et al (2009). A descriptive retrospective study of bladder cancer at a hospital in Iran (1973-2003). Asian Pac J Cancer Prev, 10, 681-4. 